\title{
Non-structural carbohydrate reserves of eelgrass Zostera marina
}

\author{
Marianne K. Burke ${ }^{1, *}$, William C. Dennison ${ }^{1, * *}$, Kenneth A. Moore $^{2}$ \\ ${ }^{1}$ Horn Point Environmental Laboratory, University of Maryland System, Cambridge, Maryland 21613, USA \\ ${ }^{2}$ Virginia Institute of Marine Science, School of Marine Science, College of William and Mary, Gloucester Point, \\ Virginia 230762, USA
}

\begin{abstract}
The high minimum light requirement of eelgrass Zostera marina L. suggests that this species has difficulty in maintaining a positive carbon balance except under high light conditions. The carbon balance of $Z$. marina can be studied by following seasonal changes in non-structural carbohydrate (NSC) reserves, however, little is known about the seasonal variation in NSC reserves in seagrasses or the influence of shading on NSC reserve content and distribution. Seasonal changes in eelgrass NSC reserves were measured in a shallow coastal lagoon, Chincoteague Bay, Maryland/Virginia, USA, near the southern edge of this species' distributional range. Concentrations of sugar varied seasonally in leaves, rhizomes and roots, with maximum concentrations occurring in the rhizomes. In contrast, starch concentrations did not vary with the season, but were highest in the roots. Seasonal peaks in rhizome NSC reserves parallel the spring and fall bimodal growth patterns observed for $Z$. marina in the region. Total NSC reserves change from an estimated 52 to $73 \mathrm{~g} \mathrm{~m}^{-2}$ in June to 4 to $18 \mathrm{~g} \mathrm{~m}^{-2}$ in January, or a decrease of 75 to $92 \%$. Experimental shading for $3 \mathrm{wk}$ in the spring reduced ( $\mathrm{p}<0.001)$ sugar but not starch concentrations in leaves $(48 \%)$, rhizomes $(40 \%)$ and roots $(51 \%)$. In addition, shading reduced $(p<0.05)$ leaf biomass $(34 \%)$, root and rhizome biomass $(23 \%)$ and density $(27 \%)$. Potential NSC reserve storage during shading was reduced by an estimated $66 \%$. Spring appears to be an important time for both growth and storage of NSC reserves in $Z$. marina, and the NSC reserves are generally depleted throughout the remainder of the year. Turbidity during this springtime 'window of opportunity' may jeopardize subsequent survival as a result of inadequate NSC reserves to maintain a positive carbon balance dunng the rest of the year.
\end{abstract}

KEY WORDS: Eelgrass - Zostera S Seagrass S Starch - Sugar - Shading · Carbon balance Biomass

\section{INTRODUCTION}

The southern distributional range of eelgrass Zostera marina L. appears to be limited by high summertime water temperatures in some areas (Dennison 1987). At the southern part of its range on the east coast of the United States (e.g. Chincoteague Bay, Maryland/Virginia), water temperatures reach $30^{\circ} \mathrm{C}$ in the summer. Because respiration exceeds photosynthesis at temper-

\section{Present addresses:}

- USDA Forest Service, Southern Research Station, $2730 \mathrm{Sa}-$ vannah Highway Charlectnn, Snuth Carolina 29414, USA. E-mail:burkem@cofc.edu

- Department of Botany, University of Queensland, Brisbane, Australia 4072 atures above $25^{\circ} \mathrm{C}$ (Marsh et al. 1986, Dennison 1987 , Zimmerman et al. 1989), summer may be a time of carbon balance depletion. Results from a number of studies show that eelgrass has a high minimum light requirement relative to other plants (Backman \& Barilotti 1976, Bulthuis 1983, Goldsborough \& Kemp 1988) and the maximal depth limit for survival of eelgrass is strongly linked to light availability (Burkholder \& Doheny 1968, Backman \& Barilotti 1976, Dennison \& Alberte 1982, 1985, 1986, Wetzel \& Penhale 1983, Dennison 1987). Results from these and other studies (Felger et al. 1980, Kenworthy et al. 1982, Robertson \& Mann 1984) suggest that high light levels are necessary for maintenance of a positive carbon (C) balance from year to year. We hypothesize that eelgrass populations on the Maryland/Virginia border are just main- 
taining a positive annual $C$ balance and, therefore, that any additional reduction in carbon reserves may result in increased mortality among these populations.

To maintain a positive $\mathrm{C}$ balance from year to year, plants must allocate photosynthate appropriately among competing sinks including roots, rhizomes, leaves, reproductive material, and storage reserves. However, the survival of eelgrass populations at the southern edge of their distributional range may depend on whether their $\mathrm{C}$ allocation patterns are flexible enough to withstand any additional environmental stresses, such as shading events.

Eelgrass at this latitude capitalizes on optimum environmental conditions during spring for growth (Orth \& Moore 1986). It is the high light availability and cool water during that season which allow high biomass production and, we hypothesize, large accumulations of non-structural carbohydrates (NSC). What is not known is wheille these plants can store enough NSC reserves to maintain a positive annual $C$ balance throughout the year if spring shading occurs. Certainly, these reserves are critical for maintenance during the subscqucnt summer, autumn and winter when temperature and light conditions limit photosynthesis and/or increase respiration rates. Declines in Zostera marina populations, attributed to increasing turbidity in some areas (Orth \& Moore 1983), led to the hypothesis that $Z$. marina is not flexible enough to change its $C$ allocation pattern to help it survive turbidity events affecting some areas in the southern part of its range. If this is the case, allocation of photosynthate to biomass production instead of storage could eventually result in a depleted $C$ balance.

A potentially important indicator of the $C$ balance in eelgrass is the concentration and distribution of NSC reserves. Seasonal NSC levels in eelgrass have seldom been measured (but see Harrison \& Mann 1975. Zimmerman et al. 1989, 1995) However, the seasonal variation of NSC reserves has been examined for several other seagrasses: the NSC reserves in Thalassia testudinum, Syringodium filiforme, and Halodule wrightii were highest in the autumn (Dawes \& Lawrence 1980) suggesting that those reserves were used to sustain plants through the winter. The influence of experimental shading on NSC reserves in naturally growing populations of Zostera marina has not been determined, although shading of $T$. testudinum was shown to reduce NSC reserves in all plant tissues (Tomasko \& Dawes 1989).
We hypothesized that NSC levels in healthy eelgrass beds in Chincoteague Bay would peak in the spring and decline during the remainder of the year as the plants used those reserves to sustain themselves through the summer, autumn and winter Further, we hypothesized that shading during the spring would lead to a reduction in NSC reserves compared to unshaded plants. We tested these hypotheses by measuring the seasonal variation in NSC concentrations and growth in a naturally growing seagrass bed and conducted a shading experiment in an adjacent part of the bed. Finally, we used Zostera marina biomass estimates to produce seasonal NSC budgets and to estimate the influence of spring shading on the annual carbon balance.

\section{METHODS}

The study was conducted during 1990 to 1992 in Chincoteague Bay $\left(37^{\circ} \mathrm{N}, 75^{\circ} \mathrm{W}\right)$, a shallow coastal lagoon located between the mouths of the Delaware and Chesapeake Bays (Fig 1). Chincoteague Bay has a

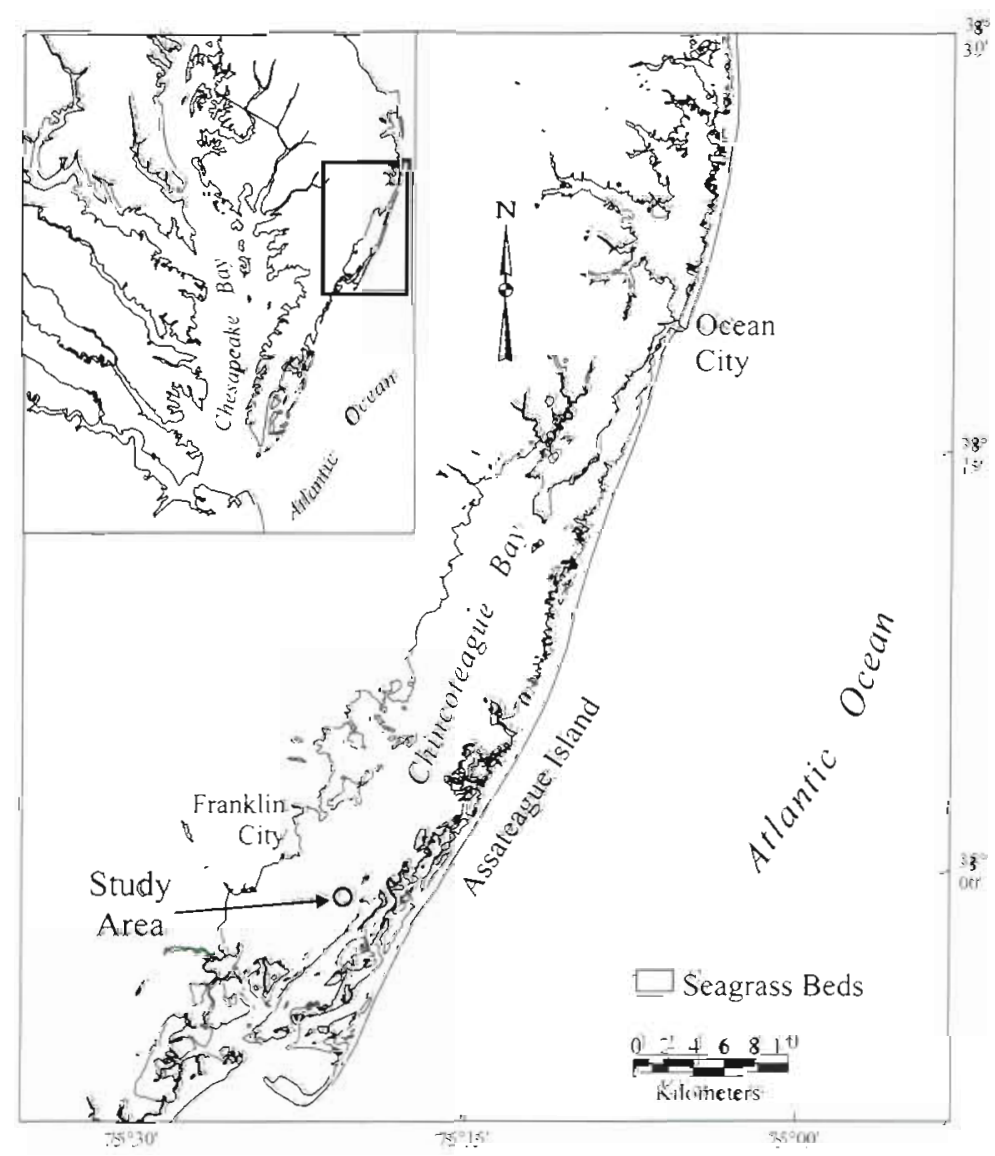

Fig. 1. Location of Chincoteague Bay on the eastern coast of the Delmarva Penunsula, USA (insert), and an enlargement of the bay, showing the distribution of eelgrass beds (shaded) and the study area 
mean depth of $1.1 \mathrm{~m}$ and inlets are situated at the north and south ends of the bay. A large bed of eelgrass exists along the barrier island (eastern) portion of the Bay, covering 2300 ha or $7 \%$ of the total bottom. Historically, the Chincoteague Bay area supported dense stands of eelgrass and now contains some of the only eelgrass populations between New Jersey and the Chesapeake Bay.

Samples of eelgrass were collected from the study site on October 30, 1990, April 23, 1991, June 4, 1991, June 25, 1991, January 8, 1992, July 6, 1992, and September 30,1992 . On each date, 3 to 12 cores $(15 \mathrm{~cm}$ diameter $\times 20 \mathrm{~cm}$ ) were collected using a hand-held auger. Each sample was placed in a zip-lock bag and was transported to the laboratory packed in an icefilled cooler Samples were stored on ice until they were processed, within $12 \mathrm{~h}$ of collection.

A field experiment was set up on June 3-5, 1991. At each of 5 locations paired groups of 4 cores were removed, placed in a PVC pipe, and then replaced in the original holes. Each core was $15 \mathrm{~cm}$ in diameter by $20 \mathrm{~cm}$ deep. Of each group, 2 were left unshaded, and 2 had shades erected directly above. Each shade was $1.8 \mathrm{~m}$ in diameter and was constructed of fine mesh fiberglass screening supported by a plastic pipe frame. The screens were buoyed at the water surface by styrofoam floats, and reduced the photosynthetically active radiation to $20 \%$ of ambient, measured using a submersible hand-held quantum sensor (Biospherical QS I-140). Fouling was kept to a minimum by cleaning screens daily.

The experimental cores were harvested on June 24-26, 1991. One of each pair was used for biomass measurements; the second was used for analysis of NSC. Two additional cores were taken from the vicinity of each replicate to compare biomass and carbon allocation patterns in the natural population and the unshaded cores. Cores were cleaned of sediment on a $1 \mathrm{~cm}$ mesh wire sieve by gently washing with seawater. The samples were stored on ice and processed within $12 \mathrm{~h}$ of collection. Samples were separated into 3 tissues: leaves, roots and rhizomes. Leaves consisted of all shoot material above the meristematic region (SandJensen 1975) and roots and rhizomes were from the first 4 internodes only. Samples for NSC analysis were cleaned of sediment and organic material by briefly washing with tap water and gently scraping to remove epiphytes and sediment. The plant tissue used for the NSC analysis was then frozen and later freeze-dried to a constant weight. The freeze-dried samples were ground to a fine powder using a Crescent Wig-L-Bug dental amalgamator and stored in a freezer $\left(-20^{\circ} \mathrm{C}\right)$.

The leaves, lihiuumes and root materiai were analyzed for soluble carbohydrates according to Burke et al. (1992). Soluble sugars (sucrose, glucose, and fruc- tose) were extracted from the ground tissue using hot $80 \%$ ethanol (Association of Official Analytical Chemists 1980$)$ and starch using cold $\left(0^{\circ} \mathrm{C}\right) 30 \%$ perchloric acid in a modified version of the Hansen \& Möller (1975) method. Sugar and starch concentrations in the extractants were then measured using the phenol-sulfuric acid colorimetric method (Hodge \& Hofneiter 1962) with an absorbance of $490 \mathrm{~nm}$. NSC content was estimated by multiplying sugar and starch concentrations by biomass values obtained from this study as well as those from 3 nearby Zostera marina populations (Orth \& Moore 1986) in a previous study.

Samples for biomass analyses were cleaned using tap water, counted and separated into leaves, roots and rhizomes. Because of the small mass of roots and difficulty in sampling them completely, roots and rhizomes were combined for biomass estimates. Epiphytes were gently removed from the leaves by scraping. Dry weight was determined after drying at $60^{\circ} \mathrm{C}$ for $2 \mathrm{~d}$ and ash free dry weight by subtraction after ashing at $550^{\circ} \mathrm{C}$ for $5 \mathrm{~h}$.

Calculations of means, standard errors, Bartlett's test for homogeneity of variance and analysis of variance (ANOVA) were performed using Systat (Wilkinson 1988) or Stastica/Mac (StatSoft Inc. 1992). When variance was heteroscedastic, data were transformed and homogeneity of variance was insured before ANOVA. were performed on the transformed data. For each significant $(p<0.05)$ ANOVA, factor level means were compared post hoc using Tukey's HSD. Significance levels reported are for the Tukey's HSD tests.

\section{RESULTS}

The concentration of NSC reserves (Table 1) was lowest in the leaves, highest in the rhizomes, and intermediate in the roots. Sugar was the dominant NSC form in the leaves (77\%) and rhizomes (84\%), while starch dominated over sugar $(31 \%)$ in the roots. Because roots comprised a small (approximately $1 \%$ ) proportion of the total biomass, they made a small contribution to the NSC reserves. The total NSC concentrations in leaves and rhizomes peak in the autumn and in late spring/early summer, and decrease to minimum levels in late summer.

Severing the rhizomes for the experiment did not influence the NSC concentrations: NSC concentrations in control and unshaded treatments were similar in each tissue type (Table 2). However, there was a strong experimental effect. Three weeks of shading resulted in a significant $(\mathrm{p}<0.001)$ reduction in sugar concentrations in leaves $(48 \%)$, rhizomes $(40 \%)$, and roots $(51 \%)$, but there were no differences in starch concentrations. 
Table 1 Zostera marina. Mean estimates of the NSC (non-structural carbohydrate) concentrations in leaves, rhizomes and roots of field grown eelgrass on 7 dates. SE = standard error of the mean

\begin{tabular}{|c|c|c|c|c|c|c|c|}
\hline \multirow[t]{2}{*}{ Date } & \multirow{2}{*}{$\begin{array}{c}\text { Sample } \\
\text { size }\end{array}$} & \multicolumn{2}{|c|}{ Leaves } & \multicolumn{2}{|c|}{ Rhizomes } & \multicolumn{2}{|c|}{ Roots } \\
\hline & & $\begin{array}{c}\text { Sugar } \\
\mathrm{mg} \mathrm{g}^{-1}(\mathrm{SE})\end{array}$ & $\begin{array}{c}\text { Starch } \\
\mathrm{mg} \mathrm{g}^{-1}(\mathrm{SE})\end{array}$ & $\underset{\mathrm{mg} \mathrm{g}^{-1}(\mathrm{SE})}{\operatorname{Sugar}}$ & $\begin{array}{c}\text { Starch } \\
\mathrm{mg} \mathrm{g}^{-1}(\mathrm{SE})\end{array}$ & $\begin{array}{c}\text { Sugar } \\
\mathrm{mg} \mathrm{g}^{-1} \text { (SE) }\end{array}$ & $\begin{array}{c}\text { Starch } \\
\mathrm{mg} \mathrm{g}^{-1} \text { (SE) }\end{array}$ \\
\hline Oct 30,1990 & $(4-8)$ & $38.4 \quad(4.0)$ & $61.6 \quad(4.2)$ & $219.0(16.5)$ & $59.7 \quad(3.3)$ & $71.3(6.4)$ & $140.1 \quad(3.7)$ \\
\hline Apr 23,1991 & (10) & $86.8 \quad(1.2)$ & $43.5 \quad(0.8)$ & $157.6(17.0)$ & $40.1 \quad(1.9)$ & $54.0 \quad(3.4)$ & $119.4 \quad(2.9)$ \\
\hline Jun 4, 1991 & (10) & $105.3 \quad(4.2)$ & $31.0 \quad(0.7)$ & $229.0 \quad(5.6)$ & $41.9 \quad(3.3)$ & $54.0 \quad(0.9)$ & $122.6(0.1)$ \\
\hline Jun 25, 1991 & (10) & $76.2(5.6)$ & $25.9(2.0)$ & $213.4 \quad(7.4)$ & $37.1 \quad(2.5)$ & $52.3(2.4)$ & $121.9(1.5)$ \\
\hline $\operatorname{Jan} 8,1.992$ & (3) & $144.4(69.3)$ & $21.6(11.4)$ & $153.5(12.5)$ & $45.4 \quad(1.0)$ & $35.2(6.7)$ & $91.2(1.0)$ \\
\hline Jul 6, 1992 & (12) & $66.8(13.5)$ & $26.3(1.5)$ & $187.9(13.7)$ & $42.8 \quad(2.5)$ & $36.4(4.6)$ & 113.8 (3.9) \\
\hline Sep 30, 1992 & (10) & $31.8 \quad(3.2)$ & $18.3(0.7)$ & $116.4(10.2)$ & $48.2 \quad(1.2)$ & $13.4(2.5)$ & $95.1(1.5)$ \\
\hline
\end{tabular}

Table 2. Zostera marina. Mean estimates of NSC concentration in leaves, rhizomes and roots in eelgrass subjected to experimental shading. Control = field grown unshaded plants; unshaded $=$ unshaded experimental plants; shaded $=$ shaded $($ to $20 \%$ ambient light for $3 w k$ ) experimental plants. $n=5$. Identical superscripts indicate non-significantly different means $(p>0.05)$

\begin{tabular}{|c|c|c|c|c|c|c|}
\hline \multirow[t]{2}{*}{ Date } & \multicolumn{2}{|c|}{ Leaves } & \multicolumn{2}{|c|}{ Rhizomes } & \multicolumn{2}{|c|}{ Roots } \\
\hline & $\begin{array}{c}\text { Sugar } \\
\mathrm{mg} \mathrm{g}^{-1}(\mathrm{SE})\end{array}$ & $\begin{array}{c}\text { Starch } \\
\mathrm{mg} \mathrm{g}^{-1}(\mathrm{SE})\end{array}$ & $\begin{array}{c}\text { Sugar } \\
\mathrm{mg} \mathrm{g}^{-1}(\mathrm{SE})\end{array}$ & $\begin{array}{c}\text { Starch } \\
\mathrm{mg} \mathrm{g}^{-1}(\mathrm{SE})\end{array}$ & $\begin{array}{c}\text { Sugar } \\
\mathrm{mg} \mathrm{g}^{-1}(\mathrm{SE})\end{array}$ & $\begin{array}{c}\text { Starch } \\
\mathrm{mg} \mathrm{g}^{-1}(\mathrm{SE})\end{array}$ \\
\hline Control & $76.2(5.6)^{a}$ & $25.9(2.0)^{a}$ & $2134(74)^{\mathrm{d}}$ & $37.1(2.5)^{\mathrm{a}}$ & $52.3(5.3)^{\circ}$ & $121.9(3.4)^{\mathrm{d}}$ \\
\hline Unshaded & $86.1(4.1)^{\mathrm{d}}$ & $23.8(0.7)^{d}$ & $214.0(4.5)^{\mathrm{d}}$ & $38.6(2.6)^{a}$ & $46.2(6.3)^{a}$ & $125.2(5.0)^{\mathrm{d}}$ \\
\hline Shaded & $44.8(1.6)^{b}$ & $25.6(1.0)^{\mathrm{a}}$ & $128.3(9.4)^{b}$ & $44.9(4.2)^{\mathrm{a}}$ & $22.8(0.9)^{b}$ & $133.6(3.4)^{\mathrm{a}}$ \\
\hline
\end{tabular}

Table 3. Zostera marina. Mean biomass, density and ash free dry weight proportion estimates in eelgrass subjected to experimental shading. Control $=$ field grown unshaded plants; unshaded $=$ unshaded experimental plants; shaded $=$ shaded (to $20 \%$ ambient light for $3 \mathrm{wk}$ ) experimental plants. $\mathrm{n}=5$. afw $/ \mathrm{dw}=$ ratio of ash free dry weight to dry weight. Identical superscripts indicate non-significantly different means $(p>0.05)$

\begin{tabular}{|c|c|c|c|c|c|c|c|c|}
\hline & $\begin{array}{r}\text { Lea } \\
\text { Dry wt } \\
\text { g shoot }^{-1}\end{array}$ & $\begin{array}{l}\text { aves } \\
\text { (SE) }\end{array}$ & $\begin{array}{l}\text { Rhizomes and roots } \\
\text { Dry wt } \\
\text { g shoot } \\
\text { (SE) }\end{array}$ & $\begin{array}{c}\text { Density } \\
\text { Shoots } \mathrm{m}^{-2}(\mathrm{SE})\end{array}$ & $\mathrm{afw} / \mathrm{d} w$ & (SE) & $\begin{array}{l}\text { Rhizomes at } \\
\text { afw/dw }\end{array}$ & and roots \\
\hline Control & 0.147 & $(0.028)^{d}$ & $0.0521 .(0.0069)^{\mathrm{a}}$ & $(317)^{\mathrm{a}}$ & 0.149 & $(0.008)^{3}$ & 0.249 & $(0.011)^{\mathrm{a}}$ \\
\hline Unshaded & 0.159 & $(0.039)^{\mathrm{a}}$ & $0.0532(0.0075)^{\mathrm{d}}$ & $(263)^{\mathrm{d}}$ & 0.155 & $(0.010)^{a}$ & 0.244 & $(0.009)^{\mathrm{a}}$ \\
\hline Shaded & 0.105 & $(0.024)^{\mathrm{b}}$ & $0.0412(0.0085)^{b}$ & $1045(11.2)^{b}$ & 0.134 & $(0.009)^{b}$ & 0.226 & $(0.010)^{b}$ \\
\hline
\end{tabular}

As with tissue NSC concentrations there was no difference in plant biomass between the unshaded treatments and the controls, therefore coring had no apparent effect on plant growth (Table 3). However, shading had a marked effect on the plants as leaf biomass per shoot decreased $34 \%$, root-rhizome biomass per shoot decreased $23 \%$ and density decreased $27 \%$ with treatment $(p<0.05)$. This resulted in a $50 \%$ reduction in biomass on an area basis. The $3 \mathrm{wk}$ of shading resulted in an estimated $66 \%$ reduction in NSC reserves: $15 \mathrm{~g}$ $\mathrm{m}^{-2} \mathrm{NSC}$ compared to $44 \mathrm{~g} \mathrm{~m}^{-2}$ in the unshaded and $42 \mathrm{~g} \mathrm{~m}^{-2} \mathrm{NSC}$ in the control plants. In addition, leaf ash free dry weight decreased from approximately $15 \%$ of leaf dry weight to $13 \%$, and root-rhizome ash free dry mass from 25 to $23 \%$ of root-rhizome dry weight.

Based on the low and high biomass values provided by Orth \& Moore (1986), NSC contents could have changed in Chincoteague Bay from 52 to $73 \mathrm{~g} \mathrm{~m}^{-2}$ in late June to 4 to $18 \mathrm{~g} \mathrm{~m}^{-2}$ in early January (rhizome biomass estimates were greater in the Chesapeake Bay study than in the Chincoteague Bay study). Thus, only 7 to $25 \%$ of the NSC stored in the naturally growing, unshaded population during the summer may have remained in January. 


\section{DISCUSSION}

Seasonal changes in NSC reserves showed an asynchrony between carbohydrate supply and the demand for use. Carbohydrates were stored in the spring and autumn, indicating that photosynthate supply was greater than demand for growth and respiration at those times. Although the tissue specific levels of NSC were similar during the spring and autumn, shoot specific levels were much lower during the autumn as rhizome biomass is greatly reduced at this time (Orth \& Moore 1986). Hence, spring is the major period for NSC accumulation and levels declined throughout the summer because respiration rates are higher than photosynthesis at this time (Evans et al. 1986).

These seasonal peaks in rhizome NSC reserves parallel the spring and fall bimodal growth pattern observed for Zostera marina populations in this region (Orth \& Moore 1986). This pattern of growth is in contrast to eelgrass growth in other areas where lower summertime water temperatures are associated with a single peak growth period in the summer (e.g. Jacobs 1979j. Zimmerman et al. (1995) concurrently measured seasonal patterns of growth, biomass and NSC reserves in transplanted eelgrass in one such area and demonstrated that in San Francisco Bay populations NSC reserves were greatest during the summer and declined to seasonal lows during the winter as photosynthetic performance decreased. Thus, periods with optimum growth conditions, whether in the spring, summer or autumn, also are important for the accumulation of NSC reserves in $Z$. marina. These reserves can be important for support of metabolic activity and growth during other seasons when environmental conditions are limiting.

Seasonal fluctuations in NSC reserves also occurred in Syringodium filiforme and Halodule wrightii, but not for the seagrass Thalassia testudinum (Dawes \& Lawrence 1980). This suggests that some but not all seagrass species have well-defined seasons of NSC reserve storage and depletion. These fluctuations reflect periods when photosynthate availability exceeds the need for growth and/or respiration (NSC storage) versus periods when growth and/or respiration exceeds photosynthate availability (NSC depletion). The storage of reserves during one season for use during other seasons is characteristic of plants subjected to extreme seasonal conditions (Osmond et al. 1987, Chapin et al. 1990).

Consistent with previous findings for Zosteraceae (Drew 1979, Zimmerman et al. 1989), a large proportion of the NSC reserves was stored as sugar. The reason that eeigrass has large sugar reserves relative to reserves of other plants is unclear, but sugar is an immediately available substrate for respiration, and reserves of sugar rather than starch may improve the chance of survival when unpredictable environmental stresses may occur. In addition, energy is saved by not converting sugar to starch and then back to sugar.

It is not immediately apparent why our estimates of peak NSC reserves were so much lower than the 400 and $600 \mathrm{mg} \mathrm{g}^{-1}$ reported for leaves and rhizomes for the California populations of Zostera marina (Zimmerman et al. 1989, 1995). A possible explanation is that the Chincoteague populations are subject to greater extremes in temperature, up to $30^{\circ} \mathrm{C}$, and the California populations experience a much smaller temperature range of 12 to $17^{\circ} \mathrm{C}$. Because respiration exceeds photosynthesis at temperatures greater than $25^{\circ} \mathrm{C}$ (Zimmerman et al. 1989), $Q_{10}$ values of 2.4 and 1.6 respectively (Marsh et al. 1986), the Chincoteague $Z$. marina population may spend extended periods during the summer respiring away stored reserves. However, Zimmerman et al. (1995) reported that reduced plant photosynthetic performance combined with low light availability in the winter resulted in decreases in NSC from summertime highs of 450 to $550 \mathrm{mg} \mathrm{g}^{-1}$ to annual minimums in NSC of 50 to $150 \mathrm{mg} \mathrm{g}^{-1}$ in San Francisco Bay populations. These are comparable to our minimum values (Table 1), and suggest a similar annual balance between NSC reserve accrual and loss, in spite of different annual patterns of allocation.

Clear water in the spring is critical to the survival of populations of Zostera marina because spring is an important time for growth and accumulation of energy reserves in eelgrass. It is likely that the NSC reserves accumulated during this time of year sustain the plants through other periods when respiration may exceed photosynthesis and NSC reserves can drop by 75 to $92 \%$. Springtime turbidity has potentially serious ramifications. Three weeks of turbidity could reduce the amount of potentially accumulated NSC reserves by $66 \%$ during that time period, increase the risk for exhaustion during subsequent periods of stress, and thus jeopardize overwintering and perhaps even summer survival. In addition, as in other angiosperms, a low carbon balance in eelgrass may enhance susceptibility to opportunistic pathogens (Short et al. 1988 , Burkholder et al. 1992).

Apparently, eelgrass has limited flexibility in the way in which it allocates $\mathrm{C}$ among competing sinks. Under shaded conditions in the spring, allocation to new biomass still superseded allocation to storage. Subsequently, the greater reduction in NSC storage compared to growth resulted in a reduced tissue specific level of NSC reserves. Thus, there was more biomass to be maintained with less substrate, a situation analogous to the decline in carbon documented in Zostera marina grown in nitrate-fertilized water (Burkholder et al. 1994). Apparently, the abiotic factors of 
reduced light, elevated water column nitrate, and warm temperatures act alone or in concert to depress the carbon balance in $Z$. marina. Probably, it is this compromised condition that causes eelgrass populations to decline during the warm summer months in the southern part of its distributional range.

The small amount of NSC reserves in these plants in January, 8 to $25 \%$ of spring reserve levels, illustrate the small margin of safety afforded eelgrass at this southern limit to its range. Even under optimum water quality conditions the carbon balance may approach zero in the summer as a result of net carbon loss from respiration. It is no surprise that eelgrass populations in this region decline when turbidity events coincide with the spring growing season, which represents the major 'window of opportunity' for storage of NSC reserves by eelgrass.

Arknowledgements. This research was supporteci by ivoAA Coastal Ocean Program: Estuarine Habitat Program, under a Virginia grant to the Virginia Graduate Marine Science Consortium and the Virginia College Program. The authors thank George Ward for the use of the NOAA facility at Franklin City, Virginia, as a base of operation, R. J. Orth, J. Goodman, $\mathrm{J}$. Cleveland and D. Moreno for field assistance, and Karin Maher for laboratory assistance. The authors also thank Alan $J$ Lewitus and 4 anonymous reviewers for critical and very helpful reviews of an earlier manuscript. This is contribution no. 2726 from the University of Maryland Center for Environmental and Estuarine Science and contribution no. 1994 from the Virginia Institute of Marine Science, School of Marine Science, College of William and Mary.

\section{LITERATURE CITED}

Association of Official Analytical Chemists (1980) Official methods of the Association of Official Analytical Chemists 13th edn. Washington, DC

Backman TW, Barilotti DC (1976) Irradiance reduction: effects on standing crops of the eelgrass Zostera marina in a coastal lagoon. Mar Biol 34:33-40

Bulthuis DA (1983) Effects of in situ lught reduction on density and growth of the seagrass Heterozostera tasmanica (Martens ex. Aschers) in Western Port, Victoria, Australia. J Exp Mar Biol Ecol 676:91-103

Burke MK, Raynal DJ, Mitchell MJ (1992) Soil nitrogen availability influences seasonal carbon allocation patterns in sugar maple (Acer saccharum). Can J For Res 22:447-456

Burkholder JM, Glasgow HB Jr, Cooke JE (1994) Comparative effects of water-column nitrate enrichment on eelgrass Zostera marina, shoalgrass Halodule wrightii, and widgeongrass Ruppia maritima. Mar Ecol Prog Ser 105: $121-138$

Burkholder JM, Mason KM, Glasgow HB Jr (1992) Water-column nitrate enrichment promotes decline of eelgrass Zostera marina: evidence from seasonal mesocosm experiments. Mar Ecol Prog Ser 81:163-178

Burkholder PR, Doheny TE (1968) The biology of eelgrass (with special reference to Hempstead and South Oyster Bays, Nassau County, Long Island, New York). Department of Conservation and Waterways, Town of Hempstead, NY, Contribution No. 3
Chapin FS III, Schulze E, Mooney HA (1990) The ecology and economics of storage in plants. A Rev Ecol Syst 21. $423-447$

Dawes CJ, Lawrence JM (1980) Seasonal change in the proximate constituents of the seagrasses Thalassia testudinum, Halodule wrightii, and Syringodium filforme. Aquat Bot 8 : $371-380$

Dennison WC (1987) Effects of light on seagrass photosynthesis, growth and depth distribution. Aquat Bot 27:15-26

Dennison WC, Alberte RS (1982) Photosynthetic response of Zostera marina $\mathrm{L}$. eelgrass to in situ manipulations of light intensity. Oecologia 55:137-144

Dennison WC, Alberte RS (1985) Role of daily ljght period in the depth distribution of Zostera marina (eelgrass). Mar Ecol Prog Ser 25:51-61

Dennison WC, Alberte RS (1986) Photoadaptation and growth of Zostera marina L. (eelgrass) transplants along a depth gradient. J Exp Mar Biol Ecol 98:265-282

Drew EA (1979) Physiological aspects of primary production in seagrasses. Aquat Bot 7:139=150

Evans AS, Webb KL, Penhale PA (1986) Photosynthetic temperature acclimation in two coexisting seagrasses, Zostera marina L. and Ruppia maritima L. Aquat Bot 24:185-197

Felger RS, Moser EW, Moser MB (1980) Seagrasses in Seri Indian culture. In: Phillips RC, McRoy CP (eds) Handbook of seagrass biology: an ecosystem perspective. Garland Press, New York, p 261-276

Goldsborough WJ, Kemp WM (1988) Light responses of a submersed macrophyte: implications for survival in turbid waters. Ecology 69:1775-1786

Hansen J, Moller IB (1975) Percolation of starch and soluble carbohydrates from plant tissue for quantitative determination with anthrone. Analyt Biochem 68:87-94

Harrison PG, Mann KH (1975) Chemical changes during the seasonal cycle of growth and decay in eelgrass (Zostera marinaj on the Atlantic coast of Canada. J Fish Res Bd Can $32: 615-621$

Hodge JE, Hofneiter BT (1962) Determination of reducing sugars and carbohydrates. In: Whisler RL, Wolfram JL (eds) Methods in carbohydrate chemistry, Vol 1: Analysis and preparation of sugars. Academic Press, New York, p 380-394

Jacobs RPWM (1979) Distribution and aspects of the production and biomass of eelgrass, Zostera marina L. at Roscoff, France. Aquat Bot 7:151-172

Kenworthy WJ, Zieman JC, Thayer GW (1982) Evidence for the influence of seagrasses on the benthic nitrogen cycle in a coastal plain estuary near Beaufort, North Carolina (USA). Oecologia 54:152-158

Marsh JA, Dennison WC, Alberte RS (1986) Effect of temperature on photosynthesis and respiration in eelgrass (Zostera marina L.). J Exp Mar Biol Ecol 101:257-267

Orth RJ, Moore KA (1983) Chesapeake Bay: an unprecedented decline in submerged aquatic vegetation. Science 222:51-53

Orth RJ, Moore KA (1986) Seasonal and year-to-year variations in the growth of Zostera marina L. (eelgrass) in the lower Chesapeake Bay. Aquat Bot 24:335-341

Osmond CB, Austin MP, Berry JA (1987) Stress physiology and the distribution of plants. Bioscience 37:38-48

Robertson AI, Mann KH (1984) Disturbance by ice and lifehistory adaptations of the seagrass Zostera manna. Mar Biol 80:131-141

Sand-Jensen K (1975) Biomass, net production and growth dynamics in an eelgrass (Zostera marina L.) population in Vellerup Bi, Denmark. Ophelia 14:185-201

Short FT, Ibelings BW, den Hartog C (1988) Companson of a 
current eelgrass disease to the wasting disease in the 1930 's. Aquat Bot 30:295-304

StatSoft, Inc (1992) Statistica/Mac. Tulsa, OK

Tomasko KA, Dawes CJ (1989) Evidence for physiological integration between shaded and unshaded short shoots of Thalassia testudinum. Mar Ecol Prog Ser 54:299-305

Wetzel RG, Penhale PA (1983) Production ecology of seagrass communities in the Lower Chesapeake Bay. Mar Tech Soc J 17:22-31

Thus article was submitted to the editor
Wilkinson L (1988) Systat: the system for statistics. Systat, Inc, Evanston, IL

Zimmerman RC, Reguzzoni JL, Alberte RS (1995) Eelgrass (Zostera marina L.) transplants in San Francisco Bay: role of light availability on metabolism, growth and survival. Aquat Bot 51:67-86

Zimmerman RC, Smith RD, Alberte RS (1989) Thermal acclimation and whole-plant carbon balance in Zostera marina L. (eelgrass). J Exp Mar Biol Ecol 130: 93-109

Manuscript first received: August 16, 1995

Revised version accepted: March 8, 1996 